\title{
New Brunswick's Forest Policy — Facing the Future
}

\author{
by
}

\author{
Robert S. Watson 1
}

Two years ago New Brunswick implemented a new forest policy establishing a new institutional framework for the management of the province's forest resources, both public and private, in the decades ahead. The new policy required more than minor amendments in legislation and contractual arrangements between industry and government. It required a complete overhaul of the existing system of resource allocation and management. The process of developing and instituting this policy was initiated in 1971 and completed in 1981. The new policy became a reality on April 1, 1982. The following summarizes the major elements of forest management critical to formulating the new policy, a brief outline of past policies, the evolution of the new policy and a description of its implementation.

New Brunswick contributes only $4.3 \%$ of the total value of output to of the national forest-based industry and contributes only $5.4 \%$ of the total national harvest. Yet this contribution is based on only $2.8 \%$ of the productive forest land in Canada and on only $2.6 \%$ of the total growing stock. Compared with the rest of Canada, the forest resources of New Brunswick are highly utilized, particularly in primary production. Although not all of the characteristics of the resource, its ownership and the industry are applicable across Canada, New Brunswick's need for new policies under conditions of high utilizaiton and a rapidly aging growing stock, make New Brunswick a microcosm of issues for other jurisdictions. Its experience may prove useful to those jurisdictions facing similar conditions.

\section{Major Resource Management Concerns in New Brunswick}

The forestry sector has long been the mainstay of the province's economy. The sector plays an important role in all regions of the province, in both rural and urban economies. Productive forest land accounts for $85 \%$ of the province's land area and supports its largest industry. The forest industry employs a third of the workers in manufacturing and accounts for $40 \%$ of the province's manufacturing output.

The dominant component of the forest-based industry is pulp and paper production. There are ten pulp mills in the province, two of which produce newsprint. The plup mills utilize $80 \%$ of the total wood fibre required by all primary processing plants, of which $84 \%$ is softwood and $16 \%$ is hardwood. The other major component is lumber production. There are 99 mills whose operations are at a commercial level, but nearly half of these produce less than 2 million board feet annually. Almost two thirds of the province's sawmilling capacity is owned by the pulp and paper companies and are part of an integrated operation. All eight mills with annual capacities in excess of 25 million board feet are owned by these companies. Approximately $87 \%$ of the total softwood used annually in the province is consumed by these integrated operations.

The forest is $74 \%$ softwood with spruce and fir being the dominant species. Relative to other areas in Canada, the

'Director, Policy \& Planning, New Brunswick Department of Natural Resources. resource is easily accessible with only minor volumes more than 100 miles from any major user and most an approximate average distance of only 60 miles. There are three major groups of forest resource owners: the Crown with $48 \%$, the forest industry with $21 \%$ and non-industrial owners, mainly of small woodlots with $31 \%$

The age structure of the softwood forest creates both opportunities and constraints for management. Approximately $55 \%$ of the softwood forest is mature to overmature. The next largest area, approximately $30 \%$, is very young, less than 25 years old. In between the two major groups is a small portion of immature forest. The combination of the age class structure of the softwood forest, the volume of growing stock and the average annual roundwood demand of the mills, results in the sustainable annual supply of softwood being $20 \%$ less than industrial requirements. This shortfall assumes no silvicultural inputs to the forest. However, because of the age structure of the forest, the shortfall can be immediately overcome with an annual reforetation and stand improvement program. There are other wood supply factors that were important to the development of an appropriate forest policy. With clearcutting being the most appropriate harvesting system, obtaining the proper mix of sawlogs and pulpwood in the right balance to meet industry requirements was becoming increasingly difficult. The supply of quality logs, both hardwood and softwood, is declining relative to demand, a situation that will continue in the future. The sustainable supply of fibre-quality hardwood, while exceeding demand on a province-wide basis, is becoming a policy issue in several areas with the rapid growth in demand for fuelwood.

These characteristics and conditions of New Brunswick's forest industry and resource highlight four major management concerns that must be addressed by any forest policy which is to be relevant in New Brunswick. These concerns include the allocation and distribution of the resource and its harvest, the planning and scheduling of the harvest, protection and silviculture.

The efficient allocation and distribution of the resource and its harvest is fundamental to any forest policy. It is particularly critical in conditions of wood scarcity. This concern is complicated by the ownership pattern which involves three major groups of owners. The method of allocation of Crown timber will have an important impact on the management and allocation of timber from private lands. The characteristics of the forest and the product requirements of industry, further complicate the allocation and distribution elements of management. The forest no longer easily matches the product requirements of industry ( $\log$ vs. pulpwood, hardwood vs. softwood), and the cyclical market demands for various products further complicate the solutions for an efficient allocation and distribution system. In allocating Crown timber, there is a need to consider security of supply to industry so that investment by industry is not discouraged. Yet, the security of supply cannot be so long-term or rigid that the available Crown timber supply is not fully utilized. All of these considerations must be examined within the context of wood costs, both 
in the short- and long-term. A new policy must aim at providing the most effective allocation and distribution of the harvest on a province-wide basis from all sources.

The second important concern is planning and scheduling of the harvest. Given the age class structure and the scarcity of timber supply, any forest policy must ensure that harvest planning is done within a long-term time horizon so that shortterm expediency does not jeopardize the long-term supply. It must ensure that the older age classes are sustained to provide the required timber in the next 30 to 40 years, that the appropriate products are generated and that protection costs for budworm are minimized.

The remaining two concerns are protection and silviculture. With an old softwood forest, protection against spruce budworm damage is critical. To minimize the impact of this insect requires a combination of careful harvest planning and an effective protection program. Anything less will reduce the sustainable harvest. Silviculture is required to meet the industrial softwood requirements. It must be directed at both speeding up the regeneration of harvested stands and accelerating the growth of natural stands. A new forest policy should provide the maximum incentive to see that the required silvicultural inputs are achieved on all ownerships.

All of these elements of management are important in New Brunswick. There is very little margin for error. The major task of designing a forest policy is to provide the environment and institutional framework that recognizes these concerns and establishes a policy that provide an effective mechanism in the future to accomplish the tasks required.

\section{Policies Of The Past}

Prior to the new policy, the existing forest policy had evolved over decades with few major changes. It was essentially based on an assumption of adequate wood supply and the use of Crown timber as an incentive to increase primary processing capacity and job creation. The fee structure typified these assumptions. There were low variable costs (royalties), accompanied by fixed costs of a fire protection tax and a license renewal fee. These latter two fees were based on acreage and the volume of softwood growing stock held under license respectively.

Crown timber was allocated under a licensing system to defined areas. The licenses were for various time periods although in recent years most of them were renewed annually. Renewals were virtually automatic if all of the fees had been paid. Licenses could be bought and sold. In practice the licenses essentially provided harvesting rights with little requirement for either long-term planning or other forest management duties by the licensee.

Areas held under license varied from one to over 1700 square miles. Licenses were held by individuals or firms. Of the approximately 84 licenses, 39 were not connected to any processing facility, although these tended to be small licenses averaging approximately three square miles in area. Most of the area under license was held by the pulp and paper companies.

Approximately 95 processing plants had not formal entitlement to Crown timber for any or all of their wood needs. Areas held by licensees often bore little relationship to their wood requirements. Some licensees with processing plants had sufficient Crown timber to supply more than $100 \%$ of their own requirements and thus did not have to purchase private wood. Licensees without processing plants or a supply in excess of their needs operated as brokers of Crown timber.

Access to Crown timber was essentially controlled by the licensees. The marketing of wood from private lands was difficult, since it was in direct competition with Crown timber which was the basic source of supply for much of the industry. The system did not encourage an efficient distribution of Crown timber since the volume of Crown timber allocated under licenses no longer bore any relationship to the requirements of the licensee. Frequently the allocation of Crown timber did nothing to encourage the use of industry's own forest land.

The planning of the harvest was carried out on a year to year basis with the submission of annual harvesting plans by the licensees. The plans were generally related to the wood requirements of the licensee and the management of the license with no regard for wood from other sources. Protection was planned and implemented by the Crown as was the silviculture program.

In summary, the allocation and management policies of the past had outlived their usefulness. Industry had changed, the resource had changed. A passive form of management based on annual planning was no longer appropriate. What was required was long-term industrial and forest management planning by those managing and using the resource, an approach that encouraged more intensive management, better integration of wood processing requirements with the available supply from the forests and the full integration and use of all forest holdings regardless of ownership.

\section{Evolution of A New Forest Policy}

The need for major revisions in forest policy was widely recognized in the early 1970's. However, it also was recognized that any significant amendments to the conditions upon which industry had made or was planning investment decisions, demanded a cautious approach. Policy objectives had to be defined, problems and constraints identified and policy options formulated and evaluated. On completing this analysis intensive consultation with industry was necessary before drafting legislation embodying a new forest policy.

In 1971 the government, concerned about the future of the forest industry, the resource and the level of forest utilization, commissioned a major review of the province's forest resource potential, its potential for better utilization and the policy necessary to achieve the identified potentials. The final report (1) was completed in 1974. The recommendations were wide ranging and dealt with the total range of forest resource uses including industrial, recreational, environmental and fish and wildlife.

One of the most important recommendations was a change in the system of allocating industrial rights to Crown timber. Before completing the final report, the study group submitted an interim report in 1972 recommending that area-based licenses should be replaced by wood volume agreements without specific areas specified. They further recommended a pilot project to test the concept in one region of the province. The area selected was in the northeast region of the province containing the license of a major pulp and paper company for almost one million acres of Crown timber on which utilization of softwood was only one half the sustainable harvest on the license.

The basic elements involved in this pilot project were:

- the cancellation of the license and its replacement with a long-term wood volume agreement with the licensee;

- the forest management of the area would be the responsibility of the Province;

- a new public agency would be established to plan and coordinate the harvest and its distribution to the wood using industries in the region. The agency was to utilize the existing contractors and companies to carry out the harvest. This agency became the N.B. Forest Authority; 
- because of the under-utilization of the softwood resource, proposals would be requested for the private development of a major sawmill.

These steps were implemented and the pilot project operated until 1980.

The pilot project was not a success, although the smaller mills in the region considered it a success, receiving as they did a stable supply of logs for the first time. However, overall it did not appear to be a system that should be expanded province-wide. The reasons for the lack of success were many. The new sawmill has problems resulting from misjudgment of the quality of wood available, poor market conditions and an inadequate return for its chips. The mill eventually closed and was re-opened after modernization by the former licensee. Resolving the difficulties of the new sawmill diverted the attention of the Forest Authority from its original purpose. Market conditions made coordinating the harvesting difficult, resulting in large and costly inventories of harvested timber. Because of these problems it was very difficult to evaluate the pilot project and distinguish between problems with the basic concept and problems in implementation that would lend themselves to correction. However, perhaps the most important result of the pilot project was industry's apprehension of the approach on a provincial basis. The cooperative and positive response received from industry in the subsequent policy revisions was no doubt partly attributable to the pilot project.

As a result of the pilot project other policy options had to be evaluated. In early 1978 the basic approach was delineated, consultation with industry was held and the principles of the policy were announced in mid-1978. Two task forces were then established to advise on implementation. The task forces included a wide variety of expertise from government, industry, labour, universities and private forest owners. These task forces, one on Crown timberland allocation (2) and the other on forest management (3), reported to the Government in late 1980 and early 1981 . Thus was set the stage to draft new legislation incorporating a new provincial forest policy.

\section{The New Forest Policy}

The new policy adopted the approach that industry would manage the Crown resource under clearly defined public objectives and guidelines. Performance standards were established upon which industry would be assessed and held accountable. To put this system into place an area-based licensing system was chosen.

It was recognized at an early stage that a complete reallocation of Crown timber would be required. This meant cancelling all past licenses and agreements and issuing new rights under new conditions to those that were eligible. This required close consultation with the industry. Government established two basic conditions for receiving Crown timber under a new allocation system. Only firms with processing plants in New Brunswick would be assured access to Crown timber. The second condition was that all mills using Crown timber in the past would be assured access to Crown timber in the future under uniform conditions. These conditions established what mills received access to Crown timber. The next step was to determine, on an equitable basis, how much Crown timber.

The quantity of Crown timber that each mill would be allocated was based on the concept of Crown timber being the residual supply. This meant that all other private sources of timber and mill residues would have to be utilized first. This approach provided a mechanism to ensure levels of management on private lands similar to those on Crown lands, a stable market for wood produced on non-industrial forest lands and the maximum utilization of mill residues and of wood produced on industrial lands.

To quantify the residual requirements for each mill the following approach was employed:

1. The maximum annual volume of timber that each mill had actually used between 1975 and 1978 inclusive was selected as the maximum base demand

2. From this maximum demand, the following was substracted:

(a) the volume annually available from the private market (these shares varied according to regional supplies);

(b) the sustainable harvest from any forest land owned by the mill; and

(c) in the case of fibre users, its share of the available supply of chips.

3. The remaining volume was considered the residual to be obtained from Crown lands.

This process was followed for each product such as veneer logs, sawlogs and pulpwood and by major species group, mainly either softwood or hardwood.

The process, since it was based on the effective capacity of each mill, resulted in softwood Crown timber requirements exceeding the available supply from Crown lands by $25 \%$. This shortfall was absorbed by those firms that received licenses because the licensee had the management opportunities to increase the supply on the license and could harvest wood surplus to the sub-licensees' (see below) requirements in any year.

Issuing licenses to each mill or firm would have resulted in a large number of small license aeas. This would have jeopardized the efficient allocation and distribution of the harvest; reduced the sustainable annual supply from both an individual license and from all Crown lands; and made effective administration difficult. Furthermore, it was considered unlikely that any but the largest firms could effectively undertake the responsibilities of a licensee.

For those firms not large enough to assume the responsibilities of a licensee, a different form of allocation was provided. These firms, referred to as sub-licensees, were allocated an annual volume of the specific timber product they required. The volume was determined by their residual Crown timber requirements. They in effect have a wood volume agreement with the wood being made available on one or more licenses. The sub-licensee has no management responsibilities on the license. The licensee must honour the sub-licensee's allocation and manage the system. Sub-licensees are mainly sawmilling firms or use speical products such as veneer logs, cedar or hardwood. The sub-licensee may harvest his own allocation, contract its harvesting or have the licensee harvest it for him. These arrangements must be negotiated with the licensee.

There are ten licenses established and 115 sub-licensees. Each licensee has from six to more than 20 sub-licensees. This process established the basic long-term allocation of Crown timber. The annual allocation and distribution of the product is monitored through the annual submission of a five-year operating plan required from the licensee. This plan, in addition to outlining harvesting and silviculture plans, must include the wood requirements of the licensee and all his sub-licensees and the planned sources of wood supply. Monitoring these plans maintains a check on the annual allocation and distribution process.

The licensee is responsible for planning and scheduling the annual harvest from the license based on his wood requirements and those of his sub-licensees. The long-term harvest- 
ing plan is for 25 years and forms part of the required forest management plan for the license. The 25-year plan is critical, since it forces the licensee to assess his license area on a stand-by-stand basis and recognize any problems well in advance. The detailed harvesting plan is contained in the five-year operating plan. The forest management plan is revised every five years while the operating plan is revised annually. The licensee is permitted to vary the annual harvest within $10 \%$ of the predetermined sustainable harvest, in any one year, but must be within $5 \%$ during a five-year period.

Protection continues as a provincial responsibility but silviculture responsibilities are given to the licensee. The licensee is responsible for maintaining the productivity of the license area. Productivity will in part be determined by harvesting, protection and silviculture. The licensee must plan accordingly. Any silviculture required must ensure that harvested stands, not scheduled for planting, regenerate in a manner sufficient to replace these stands with one of similar stocking and species composition. Any of this type of silvicultural requirement is paid for by the licensee.

In issuing the license, the province determined the basic area of silviculture required annually to meet the sustainable harvest. This area may be either planted or natural stands may be cleaned and spaced. This work must be planned and carried out by the licensee to standards established by the province, which reimburses the licensee for this work at rates established by the province. The licensee may also conduct additional silviculture work at his own expense and capture its benefits in the future.

Each license is issued for 25 years, the sub-licenses are for five years. At the end of each five years, the performance of the licensee, the sustainable harvest of the license, and the utilization of the sustainable harvest are all evaluated. Should the productivity of the license be increased or maintained and other performance criteria met, then the license will be extended for an additional five years. Failure to maintain productivity will result in a reduced sustainable harvest for the license. This reduction will apply to the licensee, not his sublicensees. Failure to meet other performance standards could mean no extension of the license or at worst, cancellation of the license. In the case of sub-licensees whose agreements are renewed every year the main performance criteria is their actual timber use, compared with their allocation. If they do not use their full allocation, it could be reduced at the time of renewal.

The licensee is responsible for all forest management costs excluding protection and the basic prescribed level of silviculture. The only charge to the licensee is in the form of product specific royalties. Royalties are established each year based on fair market values. Fair market values are determined by an annual survey of private stumpage sales. Royalties are then established as a percent, set annually by regulation, of the prevailing fair market values for each species or species group and class of product (sawlogs, poles, pulpwood, etc.). Province-wide rates are used.

The terms and conditions of the new forest policy are established in the Crown Lands and Forests Act and its regulations. Each licensee enters into a Forest Management Agreement which establishes the specific terms and conditions of the license. In addition to the 25-year forest management plan and the five-year operating plan the licensee must submit a 25 -year industrial plan for his processing facilities. The industrial plan is revised every five years. A sub-licensee must submit a 10-year industrial plan to be revised every five years. In addition, as part of the Forest Management Agreement, a Forest Management Manual is issued by the province. This manual specifies utilizaiton standards, silviculture standards formats for management and operating plans and establishes standards for timber supply analysis and the data requirements from the licensee.

In summary, the new policy establishes basic objectives and standards in terms of utilization, silviculture and forest productivity that the licensee must meet. However, the licensee is given maximum felxibility for planning and integrating the total management of the license to meet or exceed these standards. It is designed to provide the licensees with the incentive to maximize the productivity and output of the license area on a sustainable basis, as well as his own private holdings. It delegates to the licensee the responsibility to plan and carry out the necessary management program. For the first time, long-term industrial and resource planning by the major users of the resource, the forest industry, is required. Given the long life cycle of the forest, long term planning is essential to achieving increased forest productivity. The policy ties together the four most important functions of forest management - planning the harvest, allocating the harvest amongst its users, silviculture and protection - into an integrated plan for implementation.

\section{References}

Report of the Forest Resources Study. Province of New Brunswick, Fredericton, NB. May, 1974

Final Report of the Task Froce on Crown Timberland Allocation to the Minister of Natural Resources. Fredericton, NB. November 1980.

Final Report of the Task Force on Forest Management to the Minister of Natural Resources. Fredericton, NB. June, 1981

\section{Woodlot Service (1978) Ltd.}

"All Matters Pertalning to Forestry"

\section{GORDON B. YOUNG, B.Sc.F., M.F. Registered Professional Forester}

320 Maple Street

Bus.: $506-472-3396$

Fredericton, N.B. 